\title{
Education and, in consequence, the Czech language hidden in the value orientations of Czech learners in the United States of America
}

Streszczenie: Rozważania podjęte w artykule dotyczą orientacji wartościujących przejawianych przez czeskich uczniów, na stałe zamieszkujących w Stanach Zjednoczonych Ameryki. W ostatnich kilkudziesięciu latach język czeski w tym kraju znajduje się w regresie. Nasi rodacy, którzy przybyli tu w trakcie głównej fali emigracyjnej w większości już się zamerykanizowali, dlatego jest niezwykle ważne, by szkoły z czeskim językiem nauczania nadal prowadziły naukę języka czeskiego oraz przekazywały informacje o czeskich realiach, co pozwoli na włączenie tego języka do systemu wartości nie tylko osób niedawno przybyłych, ale i pozostałych generacji. W badaniach własnych wykorzystano metody projekcji, służące opisowi przez uczniów preferowanych wartości, jak również pogłębionego wywiadu, umożliwiającego poznanie znaczenia języka czeskiego dla uczniów żyjących poza granicami kraju.

Słowa kluczowe: szkoła z czeskim językiem nauczania, czeski język i jego spuścizna, orientacje wartościujące, edukacja międzykulturowa, badanie jakościowe

\section{Introduction}

In the $21^{\text {st }}$ century, new demographic formulas are emerging and immigration has thus changed the nature of the language minorities not only in the European countries, but also outside them. This era of traditional patterns, which include the huge influx of foreigners from a smaller number of countries is changing into a new formula, which includes the diversity of nations comprising smaller groups from a far much broader spectrum of countries. These new patterns were described by Vertovec (2007) and named "super diversity". He illustrated this on the example of the UK as a country "with a different dynamic interplay of variables between the larger number of new, young and scattered, multinational, supranationally interlinked, socio-economic differentiated and legally stratified immigrants who arrived in the last 
decade". It examines the method by which this new diversity "is becoming a place of negotiation on language resources" not only between the newcomers, but also between the individual communities (Creese and Blackledge, 2010) and how this is manifest in the changes in language preferences. (Blommaert, 2013).

\section{Historical concept of the values in the works of J.A. Come- nius}

One of the most acclaimed trainers and pedagogues was doubtlessly Jan Ámos Comenius, whose major contribution consists in the exposure of child nature. In his theory, which he also describes in Pampaedia implores the need to learn everything substantial that would show you the way to perfection. It mainly discusses education and outlines the actual theory of life-long development.

In the generally classification of languages, it is the theory of universal language. Comenius has the opinion that universal language leads to understanding in the whole society and helps prevent events leading to conflicts and wars. Imaginary conflicts and war ate equivalent to the process of coping with the cultural differences in the inter-cultural environment. Comenius was neither the first nor last to come up with the idea of a communication language. He refers, for instance, to Vivese, Mersenne, Le Maire (Mark, unspecified year). The substantiation of these authors remain the same as that from Comenius: language confusion, uneconomical conduct at the expense of real knowledge, a source of misunderstanding and prejudices.

In pansophism, he discussed the "layout of the system of general wisdom, which would reveal the good and bad to all as well as through the unmistakable ways in which to achieve and avoid them, and where an illustration of this system is also presented, such that all the things are graded into seven categories, or worlds, thus mentioning the world of the possible or the basis of all pansophism." (Comenius, 2007). Comenius asked a question on what could lead to a benefit and improvement of the quality of the lives of all people. For him, the solution was education for all and about everything. He considered education as the orderly selection of knowledge about the world exposed to the comprehension of all people and the unifying element of human society. Just like in the case of the social theory of education making an effort to transform education and reconstruction of society (for instance, Gerou, 1992), he also made an effort at this transformation. But unlike social 
theory, he does not contend that school as an institution had been overcome, but is making an effort at its reform in the thinking of pansophism, in which he made an effort to improve education for all, as a priority for children and youth, in which he perceived the hope for a better future. He describes the programme of the pansophism school of thought in the writings Scholae vernaculea delineati (Kamínková, 1986). Life should mainly be learning and work on self-improvement.

In training and education, he did not see differences between the socio-economic classes and states or between the sexes. He wanted to provide all the youth with in-depth universal education in all sciences, arts and crafts according to their capabilities. However, education should not only be beneficial to the creation of values in the modern day, but also has a higher social significance, education is not a means to achieve something, but is an objective in itself. It is a factor of the process of humanisation of mankind, it is something that essentially shapes him. For this reason, training does not end at school, but is a life-long process and our entire life is school. Only persistent training and education makes a person a responsible citizen. Modern society places ever increasing demands on mankind and the training process must continuously adapt to these requirements. Currently, the primary criterion of success is flexibility and readiness for change.

\section{The Czech language as cultural heritage list}

It is necessary to view the status of the Czech language in the United States of America from the historical perspective. It was first transferred to this continent in the $17^{\text {th }}$ century, nevertheless its use for communication purposes started in the nineteenth century when a larger number of refugees entered the country from then Austria-Hungary. The Czech language reached its peak in this country in 1920 when 622,778 people admitted its usage. At the same time, it is possible to assume that almost all these people belonged to the active users of the Czech language because a highly compact CzechAmerican community still existed in the American cities and villages at the time, in which the Czech language was sometimes pushed completely into the background of the English language as the language of day-to-day communication. Currently, most of the so-called Czech-Americans already come from mixed ethnic families. From the cultural viewpoint, this is very serious for the Czech Republic because it is known that in mixed families, cultural Americanisation progresses much more quickly and it is only exceptionally 
rare that the conditions for generation handing down of the immigrant's language occurs (Kučera, 1990).

In terms of the numbers of Czech-speaking people, in 1980 the Czech language was 18th among the non-English languages used in the USA (Kučera, 1990) and 30 years later it was 25th. (United Census Bureau, 2019) it is thus clear that the Czech language and culture are on the retreat in the USA. For increase of the intensity of the transfer of the Czech cultural heritage, the Czech schools are working here that offer teaching of the Czech language and Czech history for the children and youth as a supplement to the day-to-day education, which these children get in the foreign schools within the primary school system. These bilingual pupils are a rich intellectual, economic and social potential for the Czech Republic. Thanks to their language and cultural knowledge, in future they shall be able to retain their Czech identity abroad and contribute to mutual understanding between nations.

\section{Methodology}

This study discusses the value orientation of the pupils who attend schools that are not completely Czech in the USA for reason of the complexity of education acquired in the territory of the USA. The partial objectives were not only to create the paradigm of their value orientation, but also identify the significance of education and the importance of the Czech language for these pupils.

Our research sample comprised children who fulfilled the following criteria:

Table 1. Research sample criteria

\begin{tabular}{|l|l|}
\hline Criterion & $\begin{array}{l}\text { The pupils growing up in a Czech or Czech-American family environment and living perma- } \\
\text { nently in the territory of the USA. }\end{array}$ \\
\hline Criterion & $\begin{array}{l}\text { During the school week, the pupils attend an American primary school, which is equivalent } \\
\text { to a Czech primary school. }\end{array}$ \\
\hline Criterion & The pupils take lessons in one of the schools that is not completely Czech in the USA. \\
\hline
\end{tabular}

The research was participated in by selected Czech schools in the USA. These schools function as incomplete schools, which provide only language training in the Czech language, and also teaching in the Czech language and Literature fields, local history in the field of Mankind and his world and History and geography of the Czech Lands up to lower and higher primary school level. 
In order to go into the depths of the value orientation of the individual pupils, we chose qualitative research, specifically, first the projective method supplemented with the in-depth interviews. firstly, the pupils got a written exercise, which was the answer to the query: What values make sense to you in your life and why?

We used thematic analysis to evaluate the transcribed interview. The data in the qualitatively oriented research are very fine, diverse and complex. Thematic analysis seems to be a suitable tool for analysis of these pitfalls. Although the thematic analysis is not defined precisely, it is frequently used. Braun and Clarke (2006) termed it as the "method of identification, analysis and reference to the samples (topics) in the data". A doubtless benefit of this method is flexibility.

In the first part of the data analysis, the pupils' texts were coded. These codes were subsequently agglomerated into topics, which represented individual values. Analysis is supplemented with the direct quotations of the statements of selected informants with whom interviews were conducted for deeper analysis. These are marked with the informant's abbreviation in brackets. For better lucidity, the quotations are written in italics.

Figure 1. Paradigm of the values created using the projective method

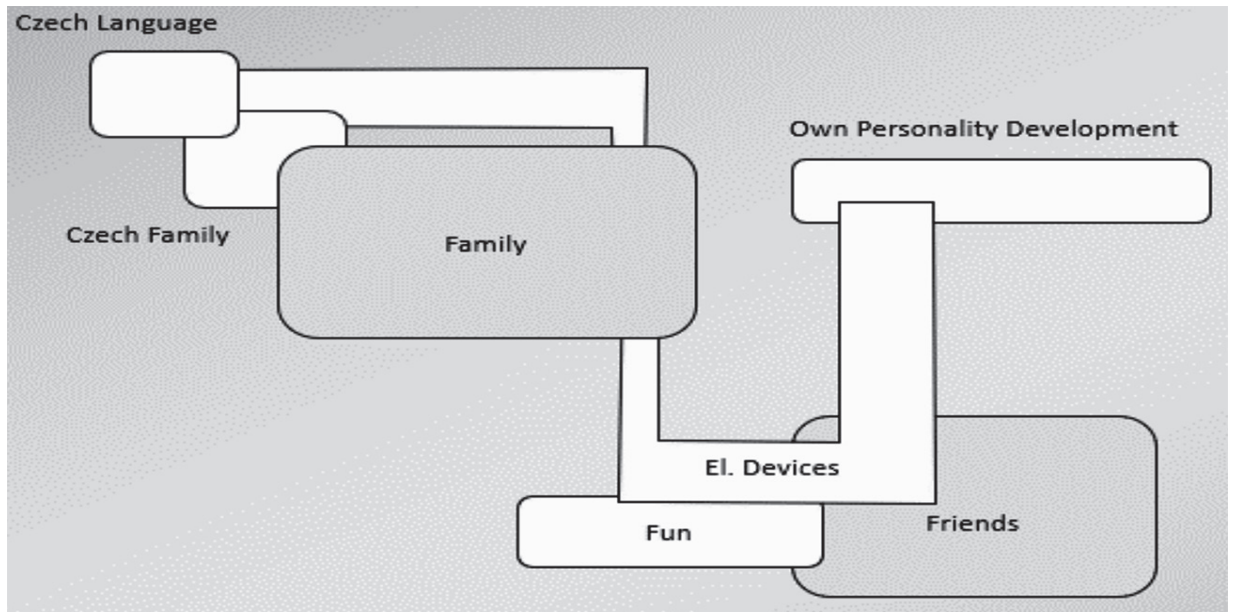

From the paradigm it is clear at first sight that the pupils wrote only about several major values. In subsequent interviews, we thus made an effort to go into the depth of these values and not add further values, nevertheless, during the data analysis we sought a link between these values and various forms 
education, which the pupils did not designate as an independent value, which is remarkable because they wrote the exercise in the school environment, or during the lessons in a Czech school. Teaching in these schools is done only in the Czech language, the interviews with the pupils were thus conducted in the Czech language.

From the paradigm, it is clear that the most important value (topic) for the pupils in the research sample is the family. It is a place that provides them with safety, assurance and a feeling of peace. They can turn to the family at any time when they have a problem or need something. Upon mention of the family, they only talked about the nuclear family around them. "The family supports me in my education in that they pay the costs, in that we live in (anonymised). School is very expensive in America." (I5). The informant also referred to the fact that education in a quality school is conditional to permanent residence in the catchment area of the concerned school and that unlike in the Czech Republic where the costs are paid by the State, school is not free for children in the USA. The family is also the first place and often apart from the Czech schools, also the only place where they hear the Czech language. It is thus very important to support this communication in this environment.

At home only my mother speaks Czech. My father's mother languages are English and Spanish. In school, there is a rule that we must speak Czech as much as possible at home, so I and my mother make an effort do so. It is sometimes difficult when I do not know some word because my mother is relentless. She gives me advice, but in the end I must say it myself [...] It is certainly an advantage, knowledge of any language is an advantage. I see this when we fly into the Czech Republic. Europe is full of different languages. Here in Florida, mostly only English and Spanish are used. (I3)

The family members living in the Czech Republic consider it as a separate value. This is for geographical reasons, the Czech Republic is too far away from the USA and they thus mostly communicate through video calls. Personal contact between the children and the Czech families is thus minimal.

I regularly talk to my Grandmother and Grandfather through Skype. We make an effort to talk to each other every week. I like seeing them and this helps me develop my language skills. They do not know English at all, I think that they learned German a long time ago. Sometimes, humorous situations occur when we simply fail to communicate. (I1)

For communication with the Czech family, it is necessary to have commu- 
nication knowledge of the Czech language. This communication knowledge together with knowledge of grammar and Czech history is acquired by the children not only in the family environment, but also in the Czech schools, which provide lessons once per week, usually on Saturdays.

I learn Czech in a Czech school and at home. We speak Czech at home and we get homework from school every week. At home, we have a minute Czech Republic so that we do not forget the language. In school, we learn geography, history and everything is focused on the Czech Republic. Last year, we for instance, celebrated the $100^{\text {th }}$ anniversary of the founding of the Czech Republic, so we had a celebration in school and also attended related lectures. Guests from the Czech Republic also flew in.(I2) The only thing that bothers me at school is that school is on Saturday when others have free time. It takes almost an hour for us to get there and for this reason I must wake-up on a day when my American classmates have free time. But otherwise it is an advantage; perhaps I will never live in the Czech Republic, but lessons in the Czech language actually enable me to get to know all Europe. We do not learn much about Europe in the USA and if so, only from the American viewpoint. (I4)

Education can also be found in the value of the virtual world, which is linked to almost all the other topics stated by the pupils in their written exercises. Work on a PC or phone develops into programming or self-study. It gives them the independence, which the informants get through the virtual world. "They have everything they need on Youtube. I learn what I don't know from there and I do not need anybody. I am capable of programming a website, make a lot of things, all thanks to the Internet." (I7). Some answers were surprising:

It also helps me with the American homework tasks. [...] I do the Czech homework through the on-line educational platform of the school. We often get various on-line exercises as homework, which are are sent to us by a Czech school. Our school has an own platform on which we can do exercises even when we cannot go to school on a given Saturday, which is a great advantage. (I7).

Unlike visiting a school institution, this concerns education in which the informants are interested and due to the fact that they are learning voluntarily in their free time and because they themselves want to do so and determine what they will learn. 
I could do without a computer, but I cannot imagine life with a mobile phone. I use it to search for homework, I have Messenger, instáč (Instagram, author's note) on it and simply everything that I need. The mobile phone is my link with the world around me. Thus both the normal and virtual world. (I1).

The value of friends and comrades certainly belong to every child or teenager. This mostly concerns classmates or peers living in the vicinity.

"I have several BFF (Best Friends Forever, author's note), but they also sometimes annoy me. After school, we sometimes go to my home or to their homes on a visit and play games." (I1) I also have good friends in the Czech school. But I admit that we speak English outside school, rather Czech-English, because it is simply easier. (I8).

The value of the development of own personality is often related to their free time, which they did not mention independently. It is just in this development that they are voluntarily learning to achieve what they like and what they would like to be in adulthood. The Czech language helps me in perspective. I know a lot about the Czech Republic and Europe. I would like to work in a Czech school at some time. Or work in diplomacy for the Czech Republic. (I5)

I am learning Czech because almost nobody knows this language. It is my secret language. I would like to communicate with my family in the Czech Republic and perhaps I will live in the Czech Republic at some time. I do not know what it is like to live in the Czech Republic. When I was younger, we always lived in the Czech Republic all summer. Sometimes only I and my sister, sometimes also with our parents. The Czech language is interesting, it is similar to Slovak and Polish. I would like to utilise this knowledge at some time. (I7).

\section{Conclusion}

The content of individual values is not discernible at first sight, and it is necessary to penetrate into their depth in order to reveal what is hidden in them. Although the pupils listed education as one of the key values, however, after penetrating deeper, it was clear that it is important for them and is actually hidden in all the mentioned values. They are proud of the fact that they have roots in the Czech Republic, but their home is already the USA. Lessons in the Czech school is presented to them in an entertaining form so that they 
enjoy it because it is extra education for them, which is not accomplished by their American classmates. These pupils are mostly born in the USA, but at least one of their parents was born in the Czech Republic and is interested in preserving the Czech language. Their children are thus the first generation in the USA, but still have links to the Czech Republic in the form of the extended family. This connection requires them to know the Czech language. Due to the fact that these pupils are very important for the Czech Republic because the maintain awareness of our country and through the knowledge of the Czech language they uphold the cultural heritage of the Czech nation and shall in future be capable of retaining their Czech identity abroad thanks to their language and cultural knowledge and this contribute to mutual understanding between nations.

It is thus more than positive that the Czech language is one of the values stated among the first values and it is necessary to positively and mainly continuously develop it in these pupils. This increases the chances that further generations of our countrymen who are proud of the land of their ancestors shall master the Czech language and their numbers shall sop declining.

As stated by some authors (Creese and Blackledge, 2010; Blommaert, 2013), for our countrymen, the USA is a place of negotiations on the language resources between the individual communities, which may be preferred in changes of language preferences.

Comenius had the opinion that universal language leads to understanding in the whole society and helps prevent events leading to conflicts and wars (Mark, unspecified year) Although a universal (artificially created) language still does not exist, but multi-lingualism, since the pupils attending the Czech schools are at minimum bi-lingual, hence multi-cultural shall certainly help to understand the individual societies. Comenius wanted to provide all the youth with deep and versatile education according to their capabilities, which the Czech schools are making an effort to provide to our pupils in spite of the sometimes complicated obstacles.

\section{Acknowledgement}

This article was based on the grant project IGA SV60171706020 / 2110 The concept of educational values from the perspective of pupils from different cultural backgrounds. However, any mistakes that remain are my own. 


\section{Bibliography}

Blommaert, J. 2013. Ethnography, superdiversity and linguistic landscapes: chronicles of complexity. Buffalo: Multilingual Matters.

Creese, A. and Blackledge, A. 2010. Towards a sociolinguistics of superdiversity. Zeitschrift für Erziehungswissenschaft. 13 (4), pp. 549-572. Also available from: http://link.springer.com/10.1007/s11618-010-0159-y.

Comenius, J.A. 2007. Obecná porada o nápravě lidských (výbor z díla). Brno: Soliton.

Marek, F. (Year not stated). Comenius and foreign languages. Ústi nad Labem: Pedagogical Faculty.

Kamínková, E. (1986). The Work of John Amos Comenius. Vyd. 1. Prague: Academia.

Kučera, K. 1990. Current status of the Czech language in the USA. Our Language. 73 (2), pp. 57-63.

Vertovec, S. 2007. Super-diversity and its implications. Ethnic and Racial Studies. 30 (6), pp. 1024-1054. Also available from: http://www.tandfonline.com/doi/abs/10.1080/01419870701599465.

United Census Bureau. 2019. [online]. USA: U.S. Department of Commerce, [cit. 2019-06-08]. Available from: https://factfinder.census.gov/faces/tableservices/jsf/pages/productview.xhtml?src=bkmk.

\section{Education and, in consequence, the Czech language hidden in the value orientations of Czech learners in the United States of America}

Abstract: This study discusses the value orientation of Czech pupils living permanently in the United States of America. The Czech language is on the decline in this country in the last decades. Our countrymen who came to this country in the major migration wave are already to a greater extent Americanized, and for this reason it is very important for the Czech schools to continue teaching the Czech language so that this language is embedded in the value orientation of not only new immigrants, but also further generations. In the research part, the projection method was applied first in which the pupils described the values that are important for them and in-depth interviews were subsequently conducted in which we 
penetrated under the surface of these values and found elements of education and significance of the Czech language for the Czech pupils living outside the Czech Republic.

Keywords: Czech school, Czech language as a heritage, value orientation, intercultural education, qualitative research

Translated by Lenka Venterová 